Mistaken Identity 



\section{Mistaken Identity}

THE SUPREME COURT AND THE

P O LITICS OF MINORIT Y

REPRESENTA TION

Keith J. Bybee 
Copyright (C) 1998 by Princeton University Press Published by Princeton University Press, 41 William Street, Princeton, New Jersey 08540 In the United Kingdom: Princeton University Press, Chichester, West Sussex All Rights Reserved

Library of Congress Cataloging-in-Publication Data Bybee, Keith J., 1965Mistaken identity : the Supreme Court and the politics of minority representation / Keith J. Bybee p. $\mathrm{cm}$. Includes bibliographical references and index. 1. Minorities - Suffrage-United States. 2. Proportional representation-United States. 3. United States. Voting Rights Act of 1965. 4. Representative government and representation-United States. 5. Election districts - United States. 6. Political questions and judicial power-United States. I. Title. KF4893.B93 1998 eISBN 1-4008-0102-8 $342.73^{\prime} 053-\mathrm{dc} 21 \quad 97-51799$ CIP http://pup.princeton.edu 
TO MY PARENTS 
